\title{
Faktor Penentu Lokasi Sentra Industri Kecil Pengolahan Hasil Perikanan Tangkap di Kawasan Pesisir Kota Pasuruan
}

\author{
Farida Puspita Rini dan Arwi Yudhi Koswara \\ Departemen Perencanaan Wilayah dan Kota, Fakultas Teknik Sipil dan Perencanaan, Institut \\ Teknologi Sepuluh Nopember (ITS) \\ e-mail: arwiyudhi@gmail.com
}

\begin{abstract}
Abstrak - Kota Pasuruan merupakan salah satu kawasan pesisir strategis penghasil sumber daya perikanan yang melimpah serta mempunyai jumlah tenaga kerja lapangan usaha perikanan yang tinggi di wilayah Provinsi Jawa Timur. Namun kondisi industri kecil pengolahan hasil perikanan tangkap yang dikelola dalam skala rumah tangga masih tersebar dan tingkat produktivitas mengalami penurunan dikarenakan belum adanya lokasi sentra industri kecil pengolahan hasil perikanan tangkap yang sesuai dan tepat untuk mendukung kegiatan produksi pengolahan perikanan tangkap kawasan pesisir Kota Pasuruan. Penelitian ini bertujuan untuk menentukan bobot faktor penentu lokasi pengembangan sentra industri kecil pengolahan hasil perikanan tangkap di kawasan pesisir Kota Pasuruan melalui teknik analisis AHP (Analytical Hirarki Process). Hasil penelitian ini menunjukkan terdapat 6 (enam) faktor dan 20 variabel penelitian dengan bobot tertinggi pada faktor bahan baku sebesar 0.248 atau $25 \%$ dari keseluruhan total bobot faktor yang ada. Sehingga bahan baku menjadi faktor prioritas pertama. Penelitian ini dilakukan di 7 kelurahan pesisir Kota Pasuruan dengan 2 (dua) tahapan penelitian.
\end{abstract}

Kata Kunci-kawasan pesisir, faktor penentu, sentra industri kecil pengolahan hasil perikanan tangkap.

\section{PENDAHULUAN}

JAWA Timur merupakan provinsi yang memiliki kawasan laut hampir empat kali luas daratannya dengan garis pantai kurang lebih $2.916 \mathrm{~km}$. Sumber daya ikan yang melimpah di laut dan juga pembudidayaan ikan di darat. Sektor perikanan mengalami peningkatan terhadap kontribusi PDRB atas dasar harga berlaku sebesar $1,92 \%$ dari tahun sebelumnya, atau setara 17 triliun rupiah [1]. Namun berdasarkan data dari Badan Pusat Statisik tahun 2015 menunjukkan tingkat kemiskinan di wilayah pesisir masih tinggi, yaitu mencapai 1,204 juta jiwa. Jumlah kemiskinan nelayan dan pembudidaya ikan masih besar. Kondisi usaha perikanan tangkap masih didominasi usaha perikanan tangkap skala kecil dengan tingkat produktivitas dan efisiensi usaha serta pendapatan yang masih rendah [2].

Kawasan pesisir Kota Pasuruan merupakan salah satu kawasan strategis penghasil sumber daya perikanan yang melimpah di Provinsi Jawa Timur. Jumlah dan proporsi perikanan tangkap di laut dalam satu tahun mencapai 1.785,6 ton dan terus mengalami peningkatan setiap tahunnya.
Diantaranya adalah produksi ikan lemuru sebesar 76.7 ton, ikan layang 103.2 ton, ikan manyung 12 ton, ikan kurisi 36.3 ton, ikan layur 17.5 ton, dengan 659 unit kapal penangkap ikan di laut [3]. Namun berdasarkan hasil wawancara dengan Kepala Kelurahan Ngemplakrejo tahun 2016, sebagian besar hasil perikanan tangkap oleh nelayan di kawasan Kota Pasuruan dijual dalam kondisi mentah kepada tengkulak dengan harga yang murah [4]. Jika hasil perikanan laut ini diolah menjadi produk olahan, maka akan menghasilkan nilai jual yang lebih tinggi 2-100 kali daripada nilai jual ikan mentah. Kondisi yang cenderung memiliki nilai keuntungan tinggi ini belum bisa dimanfaatkan oleh Pemerintah Kota Pasuruan (Dahuri, 2001).

Kondisi usaha hasil produk olahan di Kota Pasuruan pun belum bisa berkembang secara optimal dikarenakan skala produksi dalam skala industri rumah tangga dan tersebar di kelurahan-kelurahan yang ada di pesisir Kota Pasuruan. [4].

Maka penelitian ini dilakukan untuk menentukan bobot faktor penentu lokasi pengembangan sentra industri kecil pengolahan hasil perikanan tangkap di kawasan pesisir Kota Pasuruan yang sesuai dengan karakteristik industri perikanan yang ada sebagai bentuk pengendalian dan pengembangan industri kecil pengolahan hasil perikanan tangkap.

\section{METODE ANALISIS}

\section{A. Pendekatan dan Jenis Penelitian}

Pendekatan penelitian yang digunakan adalah pendekatan rasionalistik. Pendekatan rasionalistik menggunakan kebenaran metode theoritical analytic dan empirical analytic. Berdasarkan jenis penelitian, penelitian ini termasuk ke dalam penelitian deskriptif kualitatif dan kuantitatif.

\section{B. Metode Pengumpulan Data}

Data yang digunakan dalam penelitian ini merupakan data kuantitatif dan kualitatif, yang diperoleh menggunakan dua metode pengumpulan data. Pertama, pengumpulan data sekunder berupa studi literatur terkait penelitian ini. Sedangkan yang kedua adalah pengumpulan data primer yaitu wawancara yang dilakukan kepada stakeholder kunci yang sebelumnya dilakukan pemilihan stakeholder tersebut berdasarkan penilaian dengan skala likert dengan skala 1-3 (1: 
tidak penting/tidak berpengaruh, 2:cukup penting/cukup berpengaruh, dan 3:sangat penting/sangat berpengaruh).

\section{Variabel Penelitian}

Perumusan variabel penelitian didasarkan pada teori-teori yang terkait dengan penelitian ini yaitu studi literatur terkait sentra industri, teori lokasi industri, serta kajian terhadap penelitian terdahulu. Sehingga berdasarkan kajian tersebut diperoleh 6 faktor dan 20 variabel yang digunakan dalam penelitian.

Tabel 1.

Indikator dan Variabel Penelitian

\begin{tabular}{ccl}
\hline \hline No & Faktor & \multicolumn{1}{c}{ Variabel } \\
\hline 1. & Bahan Baku & Kuantitas bahan baku \\
& & Kontinuitas bahan baku \\
2. & Tenaga Kerja & Jumlah penduduk \\
& & Jumlah angkatan kerja \\
& Tenaga kerja berdasarkan umur \\
& & Tenaga kerja pada sektor perikanan \\
& & Jaringan listrik \\
3. & Infrastruktur & Jaringan air bersih \\
& & Jaringan telekomunikasi \\
& & Jaringan drainase \\
& & Sistem sanitasi \\
& & Jaringan sumber energi \\
& & Prasarana pendukung \\
& & Transportasi \\
& & Lokasi pasar \\
4. & Pasar & Potensi pasar \\
& & Aglomerasi eksisting usaha \\
5. & Aglomerasi & perikanan \\
& & Aglomerasi lokasi nelayan \\
& & Kesesuaian dengan fisik dasar \\
6. & Kesesuaian Lokasi & Kesesuaian dengan RTRW \\
& &
\end{tabular}

Sumber: Hasil Kajian Pustaka, 2016

\section{Metode Analisis}

Berikut beberapa tahapan analisis yang dilakukan.

1) Analisis Pemetaan Stakeholder

Dalam melakukan analisis pemetaan stakeholder dilihat dari tingkat kepentingan dan tingkat pengaruh stakeholder yang berada dalam satu populasi dari kelompok pemerintah dan masyarakat di wilayah penelitian.

\section{2) Analisis Bobot Faktor Penentu Lokasi dengan AHP}

(Analytical Hierarchy Process)

Untuk mencapai sasaran ini digunakan analisis pembobotan dengan menggunakan AHP (Analytical Hierarchy Process) dengan software Expert Choice 11 dengan input hasil kuesioner yang didapatkan dari stakeholder kunci penenlitian ini yang berasal dari kelompok stakeholder pemerintah dan masyarakat.

\section{HASIL DAN PEMBAHASAN}

\section{A. Analisis Pemetaan Stakeholder}

Dalam penelitian ini yang menjadi populasi penelitian adalah stakeholder yang dipih dari kelompok pihak pemerintah, pelaku usaha, dan masyarakat yang dianggap sudah mewakili dan mengetahui tentang potensi pembangunan dan pengembangan terkait penentuan bobot faktor pengembangan lokasi sentra industri kecil pengolahan hasil perikanan tangkap di kawasan pesisir Kota Pasuruan. Adapun stakeholder yang terlibat dalam penelitian adalah sebgai berikut.

1. Penduduk

a. Penduduk sekitar lokasi industri kecil pengolahan ikan tangkap

b. Pelaku usaha atau industri kecil pengolahan hasil perikanan tangkap

c. Nelayan

d. Akademisi ahli tata ruang

2. Pemerintah

a. Badan Perencanaan Pembangunan, Penelitian dan Pengembangan Daerah Kota Pasuruan

b. Dinas Perikanan Kota Pasuruan

c. Dinas Perindustrian dan Perdagangan Kota Pasuruan

d. Dinas Tenaga Kerja Kota Pasuruan

e. Dinas Cipta Karya dan Perumahan Rakyat Kota Pasuruan

f. Dinas Perhubungan Kota Pasuruan

g. Kepala Kelurahan Blandongan

h. Kepala Kelurahan Kepel

i. Kepala Kelurahan Panggungrejo

j. Kepala Kelurahan Mandaranrejo

k. Kepala Kelurahan Ngemplakrejo

1. Kepala Kelurahan Tambaan

m. Kepala Kelurahan Gadingrejo

Setelah diketahui populasi penelitian, maka dilakukan analisis tingkat kepentingan untuk menentukan sampel yang digunakan dalam analisis AHP. Analisis Stakeholders dalam penelitian ini bertujuan untuk menentukan kelompok stakeholders berdasarkan tingkat kepentingan dan pengaruhnya terhadap faktor penentu lokasi sentra industri kecil pengolahan hasil perikanan tangkap di kawasan pesisir Kota Pasuruan dengan menggunakan skala linkert dengan skala 1-3 (1: tidak penting/tidak berpengaruh yang artinya stakeholder tidak memiliki kepentingan atau tidak memiliki pengaruh terhadap tujuan penelitian, 2:cukup penting/cukup berpengaruh yang artinya stakeholder cukup memiliki kepentingan atau cukup memiliki pengaruh terhadap tujuan penelitian, dan 3:sangat penting/sangat berpengaruh yang artinya stakeholder sangat memiliki kepentingan atau sangat memiliki pengaruh terhadap tujuan penelitian). Berikut adalah hasil analisis stakeholder.

Tabel .2.

Analisis Stakeholder yang Digunakan dalam Penelitian

\begin{tabular}{|c|c|c|c|c|}
\hline $\begin{array}{c}\text { Kelompok } \\
\text { Stakeholders }\end{array}$ & $\begin{array}{l}\text { Kepentingan } \\
\text { Stakeholders }\end{array}$ & Pengaruh Stakeholders & $\begin{array}{c}\text { Tingkat } \\
\text { Kepentingan } \\
\text { Stakeholders } \\
(1-3)\end{array}$ & $\begin{array}{c}\text { Tingkat } \\
\text { Pengaruh } \\
\text { Stakeholders } \\
\text { (1-3) }\end{array}$ \\
\hline \multicolumn{5}{|l|}{ Pemerintah } \\
\hline $\begin{array}{l}\text { Badan } \\
\text { Perencanaan } \\
\text { Pembangunan, } \\
\text { Penelitian dan } \\
\text { Pengembangan } \\
\text { Daerah Kota } \\
\text { Pasuruan: } \\
\text { Bidang Ekonomi }\end{array}$ & $\begin{array}{l}\text { Pihak yang } \\
\text { mempunyai peran } \\
\text { dalam menentukan } \\
\text { kebijakan } \\
\text { pembangunan dalam } \\
\text { bidang ekonomi }\end{array}$ & $\begin{array}{l}\text { Menyusun program } \\
\text { pembankunan dan } \\
\text { kebijakan pembangunan } \\
\text { wilayah pesisir serta } \\
\text { mengkeoordinasi semua } \\
\text { kegiatan perencanaan } \\
\text { pembangunan }\end{array}$ & 3 & 3 \\
\hline $\begin{array}{l}\text { Badan } \\
\text { Perencanaan } \\
\text { Pembangunan, } \\
\text { Penelitian dan } \\
\text { Pengembangan } \\
\text { Daerah Knta } \\
\text { Pasuruan: }\end{array}$ & $\begin{array}{l}\text { Pihak yang } \\
\text { mempunyai peran } \\
\text { dalam menentukan } \\
\text { kebijakan } \\
\text { pembangunan dalam } \\
\text { bidans sarana dan } \\
\text { prasarana a dan }\end{array}$ & $\begin{array}{l}\text { Menyusun program } \\
\text { pembangunan dan } \\
\text { kebijakan pembangunan } \\
\text { wilayah pesisir serta } \\
\text { mengkoordinasi semua } \\
\text { kegiatan perencanaan } \\
\text { pembangunan }\end{array}$ & 3 & 3 \\
\hline \multicolumn{5}{|l|}{$\begin{array}{l}\text { Bidang Sarana } \\
\text { dan Prasarana }\end{array}$} \\
\hline $\begin{array}{l}\text { Dinas Perikanan } \\
\text { Kota Pasuruan }\end{array}$ & $\begin{array}{l}\text { Pihak yang } \\
\text { mengembangkan } \\
\text { sektor pengolahan } \\
\text { sumberdaya perikanan }\end{array}$ & $\begin{array}{l}\text { Menentukankebijakan } \\
\text { pengembangan dan segala } \\
\text { aktivitas sektor perikanan }\end{array}$ & 3 & 3 \\
\hline $\begin{array}{l}\text { Dinas } \\
\text { Perindustrian } \\
\text { dan } \\
\text { Perdagangan } \\
\text { Kota Pasuruan }\end{array}$ & $\begin{array}{l}\text { Pihak yang memiliki } \\
\text { kepentingan terhadap } \\
\text { kegiatan industri dan } \\
\text { perdagangan }\end{array}$ & $\begin{array}{l}\text { Menentukankebijakan } \\
\text { dan bertangggungjawab } \\
\text { terhadap kegiatan industri } \\
\text { dan perdagangan }\end{array}$ & 3 & 3 \\
\hline $\begin{array}{l}\text { Dinas Tenaga } \\
\text { Kerja Kota } \\
\text { Pasuruan }\end{array}$ & $\begin{array}{l}\text { Pihak yang memiliki } \\
\text { kepentingan terhadap } \\
\text { segala yang }\end{array}$ & $\begin{array}{l}\text { Menentukan kebijakan } \\
\text { dan bertanggung jawab } \\
\text { terhadapap pengembangan }\end{array}$ & 3 & 3 \\
\hline
\end{tabular}




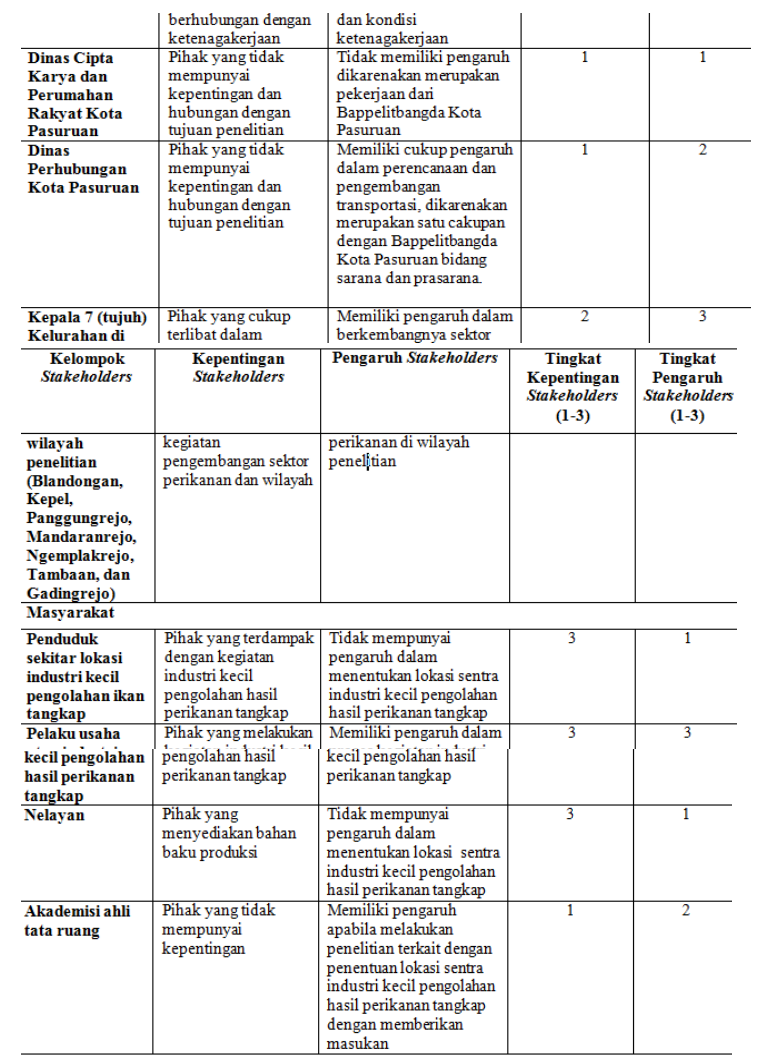

Sumber: Hasil Analisis, 2016

Sehingga stakeholder yang terpilih adalah sebagai berikut:

1. Badan Perencanaan Pembangunan, Penelitian dan Pengembangan Daerah Kota Pasuruan bidang ekonomi dan sarana prasarana (R1)

2. Badan Perencanaan Pembangunan, Penelitian dan Pengembangan Daerah Kota Pasuruan bidang sarana prasarana (R2)

3. Dinas Perikanan Kota Pasuruan (R3)

4. Dinas Perindustrian dan Perdagangan Kota Pasuruan (R4)

5. Dinas Tenaga Kerja Kota Pasuruan (R5)

6. Pengusaha industri kecil pengolahan hasil perikanan Tangkap (R6)

\section{A. Analisis Bobot Faktor Penentu Lokasi dengan AHP (Analytical Hierarchy Proccess)}

Pada penelitian ini, untuk menentukan bobot faktor penentu lokasi sentra industri kecil pengolahan hasil perikanan tangkap di kawasan pesisir Kota Pasuruan menggunakan alat analisis AHP (Analytical Hirarki Process) yang nantinya digunakan sebagai input pada analisis selanjutnya. Stakeholder yang digunakan berjumlah 6 (enam) responden. Dari hasil kuesioner diperoleh konsistensi 0,01 dengan 0 missing judgement. Karena nilai konsistensi kurang dari 0,1 maka kuesioner tidak perlu dilakukan peninjauan ulang. Hasil pembobotan dilakukan antar faktor yang ada dan variabel yang ada. Setelah dari hasil AHP ke enam responden telah dilakukan analisis, maka akan dilakukan penggabungan hasil AHP dengan fungsi combined untuk hasil prioritas gabungan. Berikut adalah hasil faktor penentu setiap responden:

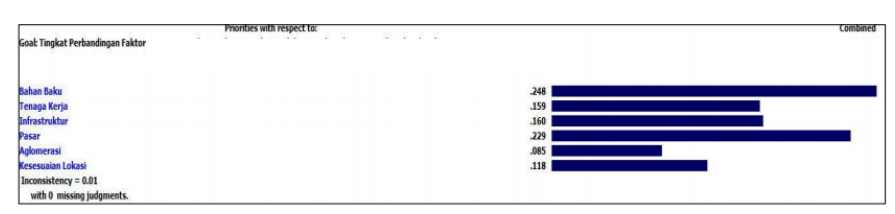

Gambar 3. Hasil AHP Faktor Combined.

Sumber: Hasil Analisis, 2017.

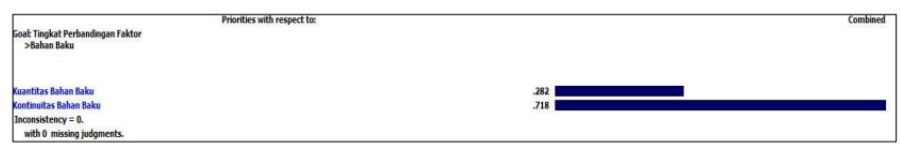

Gambar 4. Hasil AHP Faktor Bahan Baku Combined.

Sumber: Hasil Analisis, 2017.

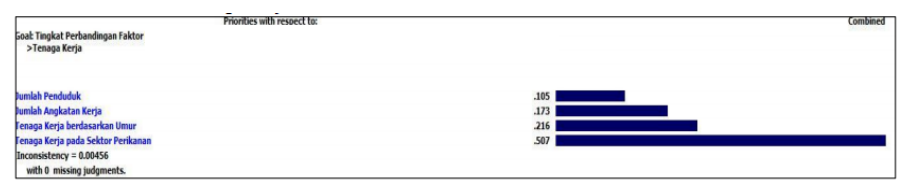

Gambar 5. Hasil AHP Faktor Tenaga Kerja Combined.

Sumber: Hasil Analisis, 2017.

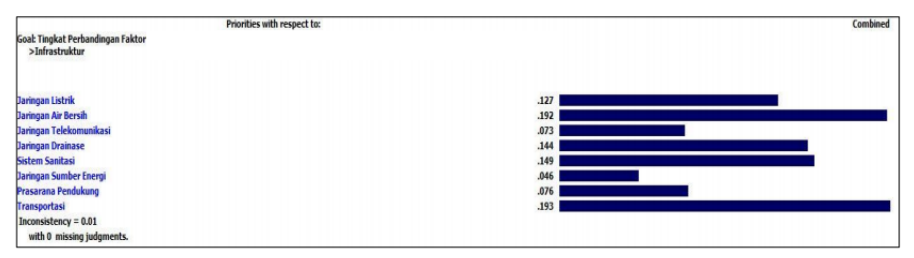

Gambar 6. Hasil AHP Faktor Infrastruktur Combined.

Sumber: Hasil Analisis, 2017.

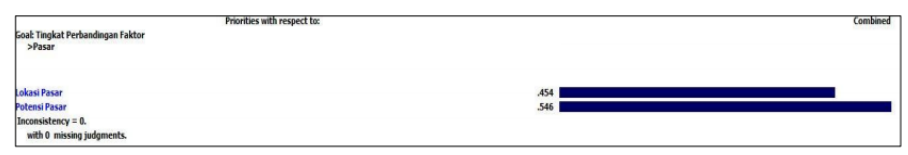

Gambar 7. Hasil AHP Faktor Pasar Combined.

Sumber: Hasil Analisis, 2017.

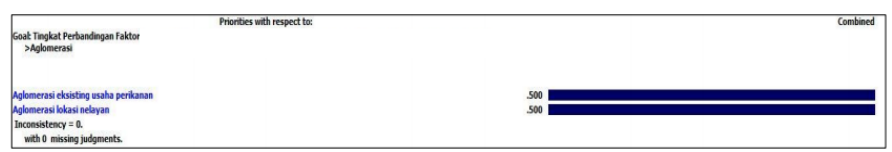

Gambar 8. Hasil AHP Faktor Aglomerasi Combined.

Sumber: Hasil Analisis, 2017.

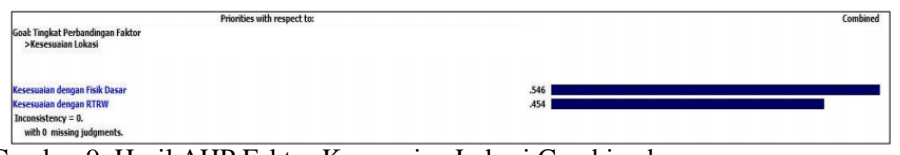

Gambar 9. Hasil AHP Faktor Kesesuaian Lokasi Combined.

Sumber: Hasil Analisis, 2017.

Hasil AHP dengan fungsi combined untuk hasil prioritas gabungan yang dibandingkan antar faktor dapat dilihat pada tabel berikut.

Tabel 5.

Bobot Faktor Penelitian

\begin{tabular}{lcc}
\hline \hline \multicolumn{1}{c}{ Faktor } & Bobot & Dalam \% \\
\hline Bahan Baku & 0.248 & $25 \%$ \\
Tenaga Kerja & 0.159 & $16 \%$ \\
Infrastruktur & 0.160 & $16 \%$ \\
Pasar & 0.229 & $23 \%$ \\
Aglomerasi & 0.085 & $9 \%$ \\
\hline \hline
\end{tabular}




\begin{tabular}{lrc}
\hline \hline Kesesuaian Lokasi & 0.118 & $12 \%$ \\
& 0.999 & $100 \%$ \\
\hline \hline Sumber: Hasil Analisis, 2017
\end{tabular}

Pada tabel tersebut dapat diketahui bahwa bahan baku mempunyai bobot faktor sebesar $25 \%$ dari keseluruhan total bobot faktor yang ada. Sehingga bahan baku menjadi faktor prioritas yang pertama. Berada diurutan kedua adalah faktor pasar dengan bobot sebesar 23\%. Sedangkan untuk faktor tenaga kerja dan infrastruktur mempunyai bobot kepentingan faktor sama yaitu sebesar $16 \%$ dari keseluruhan total bobot faktor yang digunakan. Untuk faktor kesesuaian lokasi mempunyai bobot sebesar $12 \%$ dan yang terakhir adalah aglomerasi dengan bobot $9 \%$ dari keseluruhan total bobot faktor yang ada.

Sedangkan untuk setiap variabel yang digunakan diperoleh konsistensi 0,00243 dengan 0 missing judgement. Karena nilai konsistensi kurang dari 0,1 maka hasil pembobotan dari setiap variabel dapat digunakan. Berikut adalah nilai bobot dari setiap variabel penelitian yang digunakan:

Tabel 6.

Bobot Variabel Penelitian

\begin{tabular}{lrr}
\hline \hline \multicolumn{1}{c}{ Variabel } & Bobot & Dalam \% \\
\hline Kuantitas bahan baku & 0.070 & $6.99 \%$ \\
Kontinuitas bahan baku & 0.178 & $17.81 \%$ \\
Jumlah penduduk & 0.017 & $1.67 \%$ \\
Jumlah angkatan kerja & 0.028 & $2.75 \%$ \\
Tenaga kerja berdasarkan umur & 0.034 & $3.43 \%$ \\
Tenaga kerja pada sektor perikanan & 0.081 & $8.06 \%$ \\
Jaringan listrik & 0.020 & $2.03 \%$ \\
Jaringan air bersih & 0.031 & $3.07 \%$ \\
Jaringan telekomunikasi & 0.012 & $1.17 \%$ \\
Jaringan drainase & 0.023 & $2.30 \%$ \\
Sistem sanitasi & 0.024 & $2.38 \%$ \\
Jaringan sumber energi & 0.007 & $0.74 \%$ \\
Prasarana pendukung & 0.012 & $1.22 \%$ \\
Transportasi & 0.031 & $3.09 \%$ \\
Lokasi pasar & 0.104 & $10.40 \%$ \\
Potensi pasar & 0.125 & $12.50 \%$ \\
Aglomerasi eksisting usaha & 0.043 & $4.25 \%$ \\
perikanan & 0.043 & $4.25 \%$ \\
Aglomerasi nelayan & 0.064 & $6.44 \%$ \\
Kesesuaian dengan fisik dasar & 0.054 & $5.36 \%$ \\
\hline Kesesuaian dengan RTRW & $\mathbf{0 . 9 9 9}$ & \\
& & \\
\hline
\end{tabular}

Sumber: Hasil Analisis, 2017

Pada tabel bobot variabel tersebut dapat diketahui bahwa kontinuitas bahan baku mempunyai bobot variabel tertinggi yaitu sebesar $17,81 \%$ dari keseluruhan total bobot. Serta pada urutan kedua adalah potensi pasar dengan bobot variabel sebesar 12,50\%, urutan ketiga adalah lokasi pasar dengan bobot variabel $10,40 \%$, urutan keempat adalah tenaga kerja pada sektor perikanan sebesar $8,06 \%$, urutan kelima dalah kuantitas bahan baku denganbobot variabel 6,99\% dan pada urutan terakhir adalah nilai bobot variabel jaringan sumber energi sebesar $0,74 \%$.

\section{KESIMPULAN}

Pada penelitian ini bertujuan untuk menentukan bobot faktor penentu lokasi sentra industri kecil pengolahan hasil perikanan tangkap di kawasan pesisir Kota Pasuruan. Berikut ini merupakan hasil yang diperoleh dari penelitian ini :

1. Bobot faktor penentu untuk lokasi pengembangan sentra industri kecil pengolahan hasil perikanan tangkap di kawasan pesisir Kota Pasuruan yaitu dengan tingkat bobot tertinggi adalah bahan baku mempunyai bobot faktor sebesar 25\% dari keseluruhan total bobot indikator yang ada. Bahan baku merupakan salah satu faktor yang sangat penting dalam mendukung kegiatan proses produksi industri kecil pengolahan hasil perikanan tangkap di kawasan pesisir Kota Pasuruan. Sehingga bahan baku menjadi faktor prioritas yang pertama. Berada diurutan kedua adalah faktor pasar dengan bobot sebesar 23\% yang mempengaruhi potensi distribusi dari hasil produk yang dihasilkan. Sedangkan untuk faktor tenaga kerja dan infrastruktur mempunyai bobot kepentingan faktor sama yaitu sebesar $16 \%$ dari keseluruhan total bobot faktor yang digunakan. Faktor tenaga kerja merupakan potensi yang diperlukan untuk mendukung proses produksi berjalan dengan baik dengan jumlah SDM yang tersedia. Sedangkan infrastruktur merupakan salah satu kebutuhan yang penting untuk mendukung proses pengolahan, distribusi dapat berjalan dengan efisien. Untuk faktor kesesuaian lokasi mempunyai bobot sebesar $12 \%$ dan yang terakhir adalah aglomerasi dengan bobot $9 \%$ dari keseluruhan total bobot faktor yang ada, kedua faktor tersebut merupakan faktor yang berhubungan dengan kondisi fisik lingkungan dan karakteristik sosial masyarakat, sehingga lokasi sentra industri pengolahan hasil perikanan tangkap dapat dikembangkan secara efisien, tepat guna, dan sesuai dengan kondisi lingkungan.

2. Bobot variabel penentu lokasi pengembangan sentra industri kecil hasil pengolahan perikanan tangkap di kawasan pesisir Kota Pasuruan yaitu dengan tingkat kepentingan tertinggi hingga terendah adalah dimulai dari kontinuitas bahan baku, potensi pasar, lokasi pasar, tenaga kerja pada sektor perikanan, kuantitas bahan baku, kesesuaian dengan fisik dasar, kesesuaian dengan RTRW, aglomerasi nelayan, aglomerasi eksisting usaha perikanan, tenaga kerja berdasarkan umur, transportasi, jaringan air bersih, jumlah angkatan kerja, sistem sanitasi, jaringan drainase, jaringan listrik, jumlah penduduk, prasarana pendukung, jaringan telekomunikasi, dan jaringan sumber energi.

\section{DAFTAR PUSTAKA}

[1] Kementerian Kelautan dan Perikanan, Profil Kelautan dan Perikanan Provinsi Jawa Timur Untuk mendukung Industrialisasi $K P$. Jakarta: Pusat Data, Statistik dan Informasi Kementerian Kelautan dan Perikanan, 2013.

[2] BPS Kota Pasuruan, Kota Pasuruan dalam Angka 2015. Pasuruan: Dinas Perikanan Kota Pasuruan, 2016.

[3] Dinas Perikanan Kota Pasuruan, Dokumen Hasil Perikanan Tangkap Kota Pasuruan. Pasuruan: Dinas Perikanan Kota Pasuruan, 2016. 
[4] Tim Studio Kota Pasuruan, Laporan Fakta Analisis RZBWP Kota Pasuruan. Surabaya: Perencanaan Wilayah dan Kota ITS Surabaya, 2016. 